\title{
A MICRO-HAEMATOCRIT FOR DETERMINING THE PACKED CELL VOLUME AND HAEMOGLOBIN CONCENTRATION ON CAPILLARY BLOOD
}

\author{
BY \\ R. A. MCINROY \\ From the Department of Pathology of the University of St. Andrews at the Royal Infirmary, Dundee
}

(RECEIVED FOR PUBLICATION FEBRUARY 24, 1953)

The micro-haematocrit to be described is simple to make, easy to use, and highly accurate.

In the past various types of micro-haematocrit tube have been described, roughly divisible into those sealed at one end (Epstein, 1916; Ponder and Saslow, 1930; Mason, 1934; Smith, 1936 : Grüneberg, 1942 ; Meyerstein, 1942 ; Smith, 1944 ; Harris, Gilding, and Smart, 1951; Sabine and Nickolai, 1952) and those open at both ends (Gram and Norgaard, 1923; Van Allen, 1925a and b : Guest, 1938 ; Kato, 1938 and 1940 ; Miller, 1939 ; Hamre, 1940 ; Benditt, Straube, and Humphreys, 1946 ; Shils, Sass, and Goldwater, 1952).

All these tubes suffer from drawbacks either in design or method of use. A simpler capillary micro-haematocrit tube, open at both ends, heparinized and dried before use, and effectively

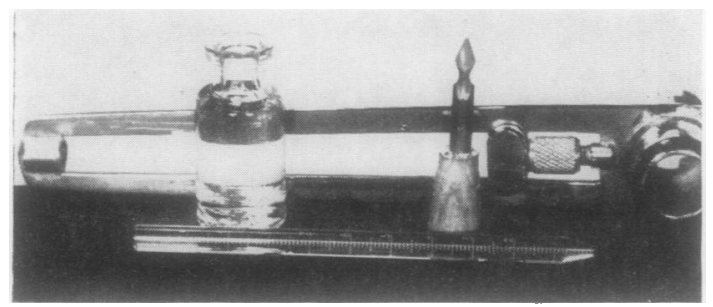

FIG. 1-Apparatus used: the centrifuge arm (haematocrit head), the micro-haematorrit tube and the stencil cutter. stored in spirit when not in use and fixed for convenience in a cork.

sealed for spinning by a simple rubber band, was introduced by Rosahn (1931). The present tube is an improved development along the same lines, and, from a single sample of capillary blood, gives both the packed cell volume (P.C.V.) and the haemoglobin $(\mathrm{Hb})$ value.

The micro-haematocrit (Fig. 1) is made from "veridia " precision-bore glass tubing* having a guaranteed internal diameter of $0.8 \mathrm{~mm} . \pm 0.01 \mathrm{~mm}$. A length

\footnotetext{
* Obtainable from Messrs. Chance Brothers Ltd., Glass Works, Smethwick, 40, Birmingham.
}

of $10 \mathrm{~cm}$. thus has a volume of $50.3 \mathrm{c.mm}$. O $(0.0503 \mathrm{ml}$.$) . The tubing was cut to fit our centri-$ fuge arm (Fig. 1), about $11.3 \mathrm{~cm}$. long and bevelled at one end, then marked from this end in millimetres and centimetres up to a length of $10 \mathrm{~cm} . \dagger$ Mercury graduation was not used. Alternatively, but less conveniently, the tube can be marked only at 5 and $10 \mathrm{~cm}$., and the P.C.V. measured by a separate millimetre rule.

\section{Technical Procedure}

Aqueous heparin solution (1,000 units $/ \mathrm{ml}$.) is drawn into the pipette to just beyond the $10-\mathrm{cm}$. mark. blown out, and the tube then dried in the $56^{\circ} \mathrm{C}$. oven.

The pipette, fitted with a rubber mouth-suction tube, is filled with capillary blood from the finger thus: (1) Blood is drawn up to a point about $5 \mathrm{~mm}$. above the $10-\mathrm{cm}$. mark. (2) The tube is wiped clean, and the upper end of the blood column is brought down exactly to the $10-\mathrm{cm}$. mark by touching the lower end against the operator's finger. (3) The measured column of blood is next carefully sucked a short distance backwards along the tube and. by means of the suction tube held in the mouth. is made to move backwards and forwards for 30 to 60 seconds in order to heparinize the blood thoroughly. This technique can easily be acquired. (4) After agitation, the column of blood is left in the capillary tube so that a small air space (about $5 \mathrm{~mm}$. long) remains at the bevelled end (Fig. 2). This small air space is important. If the tube is filled at the bedside and of has to be transported to the laboratory it is now sealed by a tightly fitting rubber band.

The tube is carefully held in an approximately horizontal position and the rubber band is removed. (The air space at the bevelled end must be retained.) The 0 tube is then inserted into a centrifuge arm of a stan- $\frac{D}{D}$ dard pattern. The point of the tube is pressed against $\stackrel{\mathcal{P}}{\rightarrow}$ a firm rubber plate in the peripheral end, and screwed in firmly. Alternatively the tube may be screwed into a metal holder of design similar to the centrifuge arm (Fig. 2), or into a reinforced rubber band (Fig. 2). If the latter is to be used for spinning it can be applied in the ward as described above.

+ The length markings were engraved for us by Messrs. Baird \& Tatlock (London) Ltd., Freshwater Road, Chadwell Heath, Essex. 
The tube, fitted in the centrifuge arm and suitably balanced, or fitted in the metal holder or the reinforced rubber band and simply inserted in the ordinary centrifuge bucket and suitably balanced, is spun at 3,000 r.p.m. for 30 minutes. The P.C.V., as a percentage, can then be read directly; during the centrifuging the air space is displaced and the top of the blood column comes to lie at the $10-\mathrm{cm}$. $(100 \%)$ mark. The reading should be made in a good light and a hand lens used if necessary to define the interface between the buffy layer and the column of packed red cells.

Haemoglobin Estimation.-The method used (Arnold, 1949) is one in which haemoglobin is determined as oxyhaemoglobin. After noting the P.C.V. the bevelled end of the haematocrit tube is immersed in $7 \mathrm{ml}$. of $0.007 \mathrm{~N}$ ammonia in a glass tube. After about a minute, to allow separation of the packed erythrocytes plugging the end of the tube, the blood column $(0.05 \mathrm{ml}$.) is blown down into the ammonia solution, which is then transferred to the colorimeter tube and the reading taken.

\section{Results Using Capillary Haematocrit}

The P.C.V. and $\mathrm{Hb}$ values were determined with the micro-haematocrit as above on samples of venepuncture blood from 50 patients. At the same time these values were determined by routine methods on the same samples of venous blood (Hb determination as above and P.C.V. by Wintrobe's method). A statistical analysis of the results showed the two methods to be interchangeable.

The P.C.V. and $\mathrm{Hb}$ values were also determined on single samples of capillary blood from 56 patients, and at the same time these values were determined by routine methods on venepuncture blood from the same 56 patients.

In six cases (Table III) difficulty was experienced in filling the pipette. Statistical analysis of the results in the 50 remaining cases (Table $I$ ) showed no significant difference between the mean values of the P.C.V. and $\mathrm{Hb}$ as obtained by the two methods. The statistical values indicate that a difference of greater than about $2 \%$ for the P.C.V., and about $4 \%$ for the $\mathrm{Hb}$, as obtained by the two methods, is unlikely, and a difference of greater than about $3 \%$ for the P.C.V. and about $6 \%$ for the $\mathrm{Hb}$ would be extremely rare.

A similar series of estimations was performed by an independent observer on 18 patients, and statistical ana'ysis again showed no significant difference.

\section{Micro-haematocrit Constants}

It can be seen from Table II that the constants for the micro-haematocrit tube compare favourably with those obtained by corresponding routine methods and with those reported by other workers.

\section{Technical Considerations}

The Capillary Blood Sample.-The necessity of obtaining blood from the finger without alteration in concentration due to artefact is shown by the results in Table III, in which haemoconcentration (Cases 4, 7, and 28) or haemodilution produced by faulty technique (Cases 1,23 , and 52 ) is considered to have been a factor.

A free flow of blood is essential, and a stab by a small stencil cutter (Fig. 1) was found to provide a freer flow of blood than is obtained by the

TABLE I

COMPARISON OF VALUES OBTAINED ON CAPILLARY BLOOD BY MICRO-HAEMATOCRIT TUBE AND ON VENOUS BLOOD BY ROUTINE METHODS

\begin{tabular}{|c|c|c|c|c|c|c|c|c|c|c|c|c|c|c|}
\hline \multirow{2}{*}{$\begin{array}{l}\text { Case } \\
\text { No. }\end{array}$} & \multicolumn{2}{|c|}{$\begin{array}{c}\text { Micro-haemato- } \\
\text { crit and } \\
\text { Capillary Blood }\end{array}$} & \multicolumn{2}{|c|}{$\begin{array}{c}\text { Routine Methods } \\
\text { and } \\
\text { Venous Blood } \\
\end{array}$} & \multirow{2}{*}{$\begin{array}{c}\text { Case } \\
\text { No. }\end{array}$} & \multicolumn{2}{|c|}{$\begin{array}{l}\text { Micro-haemato- } \\
\text { crit and } \\
\text { Capillary Blood }\end{array}$} & \multicolumn{2}{|c|}{$\begin{array}{c}\text { Routine Methods } \\
\text { and } \\
\text { Venous Blood } \\
\end{array}$} & \multirow{2}{*}{$\begin{array}{l}\text { Case } \\
\text { No. }\end{array}$} & \multicolumn{2}{|c|}{$\begin{array}{c}\text { Micro-haemato- } \\
\text { crit and } \\
\text { Capillary Blood }\end{array}$} & \multicolumn{2}{|c|}{$\begin{array}{c}\text { Routine Methods } \\
\text { and } \\
\text { Venous Blood } \\
\end{array}$} \\
\hline & $\underset{(\%)}{\text { P.C.V. }}$ & $\begin{array}{l}\mathbf{H b}^{*} \\
(\%)\end{array}$ & $\underset{(\%)}{\text { P.C.V.t }}$ & $\begin{array}{l}\mathbf{H b} \\
(\%)\end{array}$ & & $\begin{array}{c}\text { P.C.V. } \\
(\%)\end{array}$ & $\begin{array}{c}\mathbf{H b} \mathbf{b}^{*} \\
(\%)\end{array}$ & $\underset{(\%)}{\text { P.C.V. }}+$ & $\begin{array}{c}\mathbf{H b}^{*} \\
(\%)\end{array}$ & & $\underset{(\%)}{\text { P.C.V. }}$ & $\begin{array}{c}\mathrm{Hb}^{*} \\
(\%)\end{array}$ & $\underset{(\%)}{\text { P.C.V.t }}$ & $\underset{(\%)}{\mathbf{H b}^{*}}$ \\
\hline $\begin{array}{r}2 \\
3 \\
5 \\
6 \\
8 \\
9 \\
10 \\
11 \\
12 \\
13 \\
14 \\
15 \\
16 \\
17 \\
18 \\
19 \\
20\end{array}$ & $\begin{array}{l}43.5 \\
29.0 \\
33.0 \\
39.0 \\
44.5 \\
21.0 \\
23.5 \\
41.0 \\
36.5 \\
38.5 \\
39.0 \\
33.0 \\
32.5 \\
29.5 \\
44.5 \\
41.5 \\
18.5\end{array}$ & $\begin{array}{l}89 \\
57 \\
70 \\
78 \\
91 \\
43 \\
43 \\
88 \\
82 \\
79 \\
82 \\
70 \\
58 \\
60 \\
93 \\
94 \\
37\end{array}$ & $\begin{array}{l}43.5 \\
28.5 \\
32.0 \\
38.0 \\
44.5 \\
21.0 \\
22.0 \\
39.0 \\
37.0 \\
37.5 \\
39.0 \\
31.0 \\
32.5 \\
29.0 \\
45.0 \\
42.0 \\
18.0\end{array}$ & $\begin{array}{l}88 \\
57 \\
68 \\
79 \\
91 \\
46 \\
44 \\
91 \\
78 \\
81 \\
82 \\
69 \\
57 \\
59 \\
94 \\
94 \\
37\end{array}$ & $\begin{array}{l}21 \\
22 \\
24 \\
25 \\
26 \\
27 \\
29 \\
30 \\
31 \\
32 \\
33 \\
34 \\
35 \\
36 \\
37 \\
38 \\
39\end{array}$ & $\begin{array}{l}47.0 \\
41.5 \\
26.0 \\
23.5 \\
36.5 \\
25.5 \\
48.0 \\
19.5 \\
20.0 \\
40.5 \\
35.5 \\
46.5 \\
23.5 \\
21.0 \\
34.0 \\
21.0 \\
27.5\end{array}$ & $\begin{array}{r}98 \\
90 \\
44 \\
53 \\
81 \\
55 \\
103 \\
43 \\
48 \\
88 \\
81 \\
103 \\
53 \\
50 \\
76 \\
42 \\
55\end{array}$ & $\begin{array}{l}47.0 \\
43.5 \\
26.0 \\
25.0 \\
36.0 \\
26.0 \\
45.5 \\
20.0 \\
19.5 \\
41.0 \\
37.0 \\
47.0 \\
25.0 \\
20.0 \\
34.5 \\
22.0 \\
26.0\end{array}$ & $\begin{array}{r}97 \\
91 \\
48 \\
57 \\
76 \\
54 \\
104 \\
40 \\
51 \\
85 \\
83 \\
104 \\
55 \\
46 \\
75 \\
42 \\
54\end{array}$ & $\begin{array}{l}40 \\
41 \\
42 \\
43 \\
44 \\
45 \\
46 \\
47 \\
48 \\
49 \\
50 \\
51 \\
53 \\
54 \\
55 \\
56\end{array}$ & $\begin{array}{r}22.0 \\
48.0 \\
26.0 \\
29 \cdot 5 \\
45.0 \\
33.0 \\
9.5 \\
38.5 \\
28 \cdot 5 \\
14.5 \\
42.5 \\
39.5 \\
30.5 \\
9.0 \\
24.5 \\
26.5\end{array}$ & $\begin{array}{r}43 \\
104 \\
51 \\
54 \\
99 \\
69 \\
23 \\
80 \\
62 \\
34 \\
94 \\
88 \\
65 \\
20 \\
48 \\
50\end{array}$ & $\begin{array}{r}21.0 \\
48.0 \\
25.0 \\
28.0 \\
47.0 \\
31.0 \\
9.5 \\
39.5 \\
27.5 \\
14.0 \\
44.0 \\
40.5 \\
29.5 \\
9.0 \\
25.0 \\
24.5\end{array}$ & $\begin{array}{r}42 \\
104 \\
49 \\
50 \\
103 \\
66 \\
23 \\
83 \\
62 \\
33 \\
93 \\
86 \\
64 \\
19 \\
48 \\
46\end{array}$ \\
\hline
\end{tabular}


TABLE II

MICRO-HAEMATOCRIT CONSTANTS COMPARED WITH THOSE FROM OTHER SOURCES

\begin{tabular}{|c|c|c|c|c|c|c|c|}
\hline & Investigati & & $\begin{array}{l}\text { No. of } \\
\text { Observations }\end{array}$ & $\underset{(. v .)}{\text { Mean }}$ & $\begin{array}{l}\text { Standard } \\
\text { Deviation } \\
(\sigma)\end{array}$ & $\begin{array}{c}\text { Coefficient } \\
\text { of Variation } \\
(\%)\end{array}$ & $\begin{array}{l}\text { R ange } \\
(M=2 \sigma)\end{array}$ \\
\hline \multirow{5}{*}{$\begin{array}{l}\text { Author's micro- } \\
\text { haematocrit }\end{array}$} & \multirow{2}{*}{ P.C.V.* } & A & 20 & 20.6 & $0 \cdot 3$ & $1 \cdot 5$ & $20 \cdot 0-21 \cdot 2$ \\
\hline & & B & 20 & $46 \cdot 7$ & 0.5 & $1 \cdot 0$ & $45 \cdot 7-47 \cdot 7$ \\
\hline & \multirow{3}{*}{ Haemoglobin* $(\%)$} & A & 30 & $34 \cdot 8$ & 0.8 & $2 \cdot 3$ & $33 \cdot 2-36 \cdot 4$ \\
\hline & & B & 25 & $106 \cdot 9$ & $1 \cdot 3$ & $1 \cdot 2$ & $104 \cdot 3-109 \cdot 5$ \\
\hline & & C & 30 & $64 \cdot 6$ & 1.4 & $2 \cdot 2$ & $61 \cdot 8-67 \cdot 4$ \\
\hline \multirow{3}{*}{$\begin{array}{l}\text { Author's use of } \\
\text { routine method }\end{array}$} & \multirow{3}{*}{ Haemoglobin $+(\%)$} & A & 30 & 33.9 & 0.8 & $2 \cdot 4$ & $32 \cdot 3-35 \cdot 5$ \\
\hline & & B & 26 & $105 \cdot 4$ & $1 \cdot 8$ & $1 \cdot 7$ & $101 \cdot 8-109 \cdot 0$ \\
\hline & & $\mathrm{C}$ & 30 & $65 \cdot 0$ & $1 \cdot 0$ & $1 \cdot 5$ & $63-67$ \\
\hline \multirow[t]{3}{*}{$\begin{array}{l}\text { Biggs and Macmillan } \\
1948)\end{array}$} & \multicolumn{2}{|c|}{$\begin{array}{l}\text { Haemoglobin } \div(\%) \text { (neutral grey } \\
\text { photometer) }\end{array}$} & 50 & $97 \cdot 0$ & $2 \cdot 9$ & $3 \cdot 0$ & $91-103$ \\
\hline & \multicolumn{2}{|c|}{ P.C.V. $\ddagger$ (Wintrobe haematocrit) } & 50 & $45 \cdot 5$ & 0.4 & $1 \cdot 0$ & $44 \cdot 7-46 \cdot 3$ \\
\hline & \multicolumn{2}{|c|}{ P.C.V.§ (micro-method) } & 20 & $45 \cdot 4$ & 0.9 & $2 \cdot 0$ & $43 \cdot 6-47 \cdot 2$ \\
\hline Rosahn (1931) & \multicolumn{2}{|c|}{ P.C.V. (micro-method) } & 100 & - & $\begin{array}{l}0.2-0.8 \\
(\text { av. } 0.5)\end{array}$ & $\begin{array}{l}0 \cdot 6-2 \cdot 2 \\
(\text { av. } 1 \cdot 2)\end{array}$ & - \\
\hline
\end{tabular}

* Determinations made on heparinized venous blood from patients A, B, and C, using three different micro-haematocrit tubes. + Determinations made on the same sample of venous blood as $*$ above. using seven different routine pipettes. $\ddagger$ Five different observers each making 10 readings using 10 pipettes or tubes on a single sample of blood. $\S$ No details given. A series of con-

secutive readings on 10 rabbits using 10 pipettes for each animal.

triangular Hagedorn needle. The pipette should be filled promptly as soon as sufficient blood has collected at the site of puncture. The use of a pipette still wet with heparin solution led to air bubbles in the blood column, with consequent difficulty and delay in filling the tube.

Anticoagulants.-The tube dried out from heparin solution is infinitely easier to use. The efficacy of the heparin has been doubted by Hamre (1940) on the grounds that, if spinning is not done at once, the cells do not pack properly whether heparin be used wet or dry. To test this view, blood from Cases 27-56 (Tables I and III) was heparinized as described earlier, and then allowed to stand in the capillary tube held vertically for varying periods, up to seven hours, before centri- fuging. The cells packed properly, and there has been no other evidence pointing to ineffective heparinization.

TABLE III

RESULTS VITIATED BY HAEMOCONCENTRATION OR HAEMODILUTION

\begin{tabular}{|c|c|c|c|c|c|c|}
\hline \multirow{2}{*}{$\begin{array}{l}\text { Case } \\
\text { No. }\end{array}$} & \multicolumn{3}{|c|}{$\begin{array}{l}\text { Micro-haematocrit and } \\
\text { Capillary Blood }\end{array}$} & \multicolumn{3}{|c|}{$\begin{array}{l}\text { Routine Methods } \\
\text { and Venous Blood }\end{array}$} \\
\hline & $\underset{(\%)}{\text { P.C.V. }}$ & $\underset{(\%)}{\mathbf{H b}}$ & $\underset{(\%)}{\text { M.C.H.C. }}$ & $\underset{(\%)}{\text { P.C.V.† }}$ & $\begin{array}{l}\mathbf{H b} \\
(\%)\end{array}$ & $\underset{(\%)}{\text { M.C.H.C }}$ \\
\hline $\begin{array}{r}1 \\
4 \\
7 \\
23 \\
28 \\
52\end{array}$ & $\begin{array}{l}26.0 \\
26.5 \\
30.0 \\
32.5 \\
53.0 \\
32.0\end{array}$ & $\begin{array}{r}54 \\
48 \\
54 \\
71 \\
113 \\
59\end{array}$ & $\begin{array}{l}33 \cdot 2 \\
29 \cdot 0 \\
28 \cdot 8 \\
35 \cdot 0 \\
34 \cdot 1 \\
29 \cdot 5\end{array}$ & $\begin{array}{l}30 \cdot 5 \\
23 \cdot 5 \\
24 \cdot 0 \\
38 \cdot 0 \\
47 \cdot 5 \\
35 \cdot 5\end{array}$ & $\begin{array}{r}62 \\
40 \\
45 \\
84 \\
100 \\
66\end{array}$ & $\begin{array}{l}32.5 \\
27.2 \\
30.0 \\
35.4 \\
33.7 \\
29.8\end{array}$ \\
\hline
\end{tabular}

* Hb $100 \%=16 \mathrm{~g} \quad+$ P.C.V. determined by Wintrobe's method.

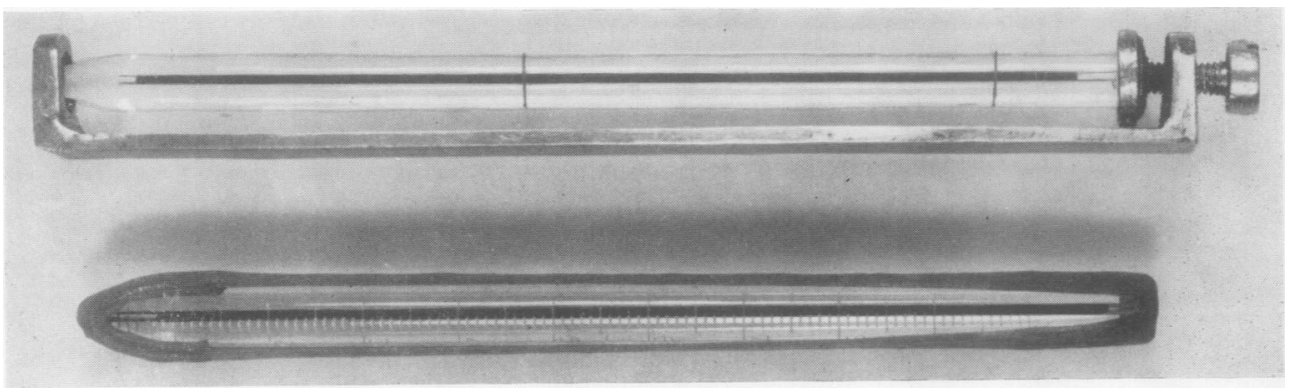

FIG. 2. Alternative sealing devices: a metal frame, having at one end an adjustable screw and at the other a sma!l firm rubber plate, or a rubber band reinforced by an automobile tyre inner tube rubber patch 
Sealing the Tube.-The variety of methods described in the past for sealing open-ended microhaematocrit tubes is an index of their unsatisfactoriness. We have found that the standard type of haematocrit head (Fig. 1), or a special metal holder as described by Kato (1938), having at one end an adjustable screw and at the other a small firm rubber plate (Fig. 2), or a rubber band reinforced on its inner surface with an automobile tyre inner tube patch (Fig. 2) $\frac{1}{2}-\frac{3}{4}$ of an inch long and fixed by means of a rubber solution, as described by Hamre (1940), serve as perfectly efficient sealing devices. When a reinforced rubber band is used as a sealing device the diameter of the tip of the pipette should be not less than $2.4 \mathrm{~mm}$, the angle of bevel not greater than $70^{\circ}$, and the rubber band should be No. 83 ( 3 in. long $\times \frac{1}{2}$ in. wide). These specifications are important.

The importance of the small air space at the bevelled end is again emphasized, permitting simple insertion of the tube into the sealing device without loss of blood.

\section{The Validity of Absolute Haematological Values Derived from Estimations on Capillary Blood}

Haemoconcentration or haemodilution can be produced by manipulations. However, when the P.C.V. and $\mathrm{Hb}$ values are derived from the same sample of capillary blood, as is the case with this micro-haematocrit tube, any deviations from the true values for the P.C.V. and $\mathrm{Hb}$, due to concentration or dilution, should be roughly proportional and the mean corpuscular haemoglobin concentration (M.C.H.C.), a value derived from these two determinations, would accordingly be little different from the true value, and this appears to be so, as can be seen in Table III.

The mean corpuscular volume (M.C.V.), on the other hand, is calculated from the P.C.V. and erythrocyte count, estimations made on two separate capillary blood samples. Accordingly, this value is liable to error if any alteration in capillary blood concentration is produced by handling at the time of either sampling. If after the haematocrit has been filled and agitated it is found that after wiping the skin surface with a swab the puncture is no longer bleeding freely, then it is essential to make a fresh stab; otherwise a false erythrocyte count will result if blood is obtained from the original puncture after undue constriction or other gross manipulation of the finger.

According to Wintrobe (1951), "It has been repeatedly shown that there is no difference in counts made on venous blood as compared with capillary blood, if proper precautions to secure a freely flowing sample are observed in each instance."

The haemoglobin content of venous and finger-tip blood shows no significant difference, although blood from the ear lobe contains about $10 \%$ more haemoglobin (Brückmann, 1942). A similar observation in cases of pernicious anaemia was reported by Duke and Stofer (1922). Capillary blood from the heel of infants is said to give a higher value than venous blood (Andresen and Mugrage, 1938 ; Mollison and Cutbush, 1949). These factors, and any degree of shock present, must all be borne in mind when haematological values are being derived from capillary blood.

\section{The Advantages of the Micro-haematocrit Tube}

With this simple and yet accurate pipette we are in a position to discover the patient's erythrocyte count, P.C.V., and $\mathrm{Hb}$ content without resorting to venepuncture, an obvious advantage in many situations. Also the micro-haematocrit's requirement of only $0.05 \mathrm{ml}$. may be useful when only a small quantity of blood is available for all investigations. For the experimentalist working with small animals this haematocrit has obvious merits.

\section{Summary}

A new micro-haematocrit, made from " veridia " precision-bore glass tubing, is described. It can be filled directly from the finger-tip, and allows determination of both packed cell volume and haemoglobin values on a single sample of capillary blood (0.05 ml.).

This is a simple instrument, and if used as detailed gives extremely accurate results. It is of clinical importance to be able to obtain these haematological values from capillary blood.

I would like to thank Professor A. C. Lendrum for his kind encouragement, assistance, and advice at different stages during the preparation of this paper. I am also deeply indebted to Dr. T. E. Faulkner for the statistical analysis of results. My thanks are also due to Dr. C. G. Woods, who performed the control series of observations, Mr. P. Harrison for the photograph (Fig. 2), and Mr. J. W. Brodie, who made the special metal holder.

\section{REFERENCES}

Andresen, M. I., and Mugrage, E. R. (1938). Amer. J. clin. Path., 8, 46

Arnold, P. (1949). Bull. Inst. med. Lab. Tech., 14, 137.

Benditt, E. P., Straube, R. L., and Humphreys, E. M. (1946). Proc. Soc. exp. Biol. N.Y., 62, 189

Biggs, R., and Macmillan, R. L. (1948). Journal of Clinical Pathology, 1, 269.

Brückmann, G. (1942). J. Lab. clin. Med., 27, 487.

Duke, W. W., and Stofer, D. D. (1922). Arih. intern. Med., 30, 94. 
Epstein, A. A. (1916). J. Lab. clin. Med., 1, 610. Gram, H. C., and Norgaard, A. (1923). Arch. intern. Med., 31,

Miller, A. T. (1939). J. Lab. clin. Med., $24,547$.

Mollison, P. L., and Cutbush, M. (1949). Brit. med. J., 1, 123.

Ponder, E., and Saslow, G. (1930). J. Physiol., Lond., 70, 18

Grüneberg, H. (1942). J. Genet., 43, 45

Guest, G. M. (1938). J. Lab. clin. Med., 24, 75.

Hamre, C. J. (1940). Ibid., 25, 547.

Rosahn, P. D. (1931). Proc. Soc. exp. Biol. N.Y. 20, 491

Harris, D. T. Gilding, H. P., and Smart, W. A. M. (1951). Experimental Physiology for Medical Students, 5 th ed., p. 22. Churchill,

Shils, M. E., Sass, M., and Goldwater, L. J. (1952). Amer. J. clin. Path., 22, 155 .

Smith, C.'H. (1936). Amer. J. med. Sci., 192, 73.

London.

Kato, K. (1938). J. Lab. clin. Med., 23, 980

Mason, S. J. (1934). J. Lab. clin. Med., 20, 318

Meyerstein, W. (1942). J. Physiol., Lond., 101, 5P.

Smith, S. E. (1944). J. Lab clin Med. 29,301

Van Allen, C. M. (1925a). Ibid., 10, 1027.

(1925b). J. Amer. med. Ass., 85, 2033.

Wintrobe, M. M. (1951). Clinical Hematology, 3rd ed., p. 301. Kimpt in London. 